\title{
Fir (Abies spp.) stand biomass additive model for Eurasia sensitive to winter temperature and annual precipitation
}

\author{
Vladimir A. Usoltsev ${ }^{1,2}$, Katarína Merganičová ${ }^{3,4}$, Bohdan Konôpka ${ }^{4,5 *}$, \\ Anna A. Osmirko ${ }^{1}$, Ivan S. Tsepordey ${ }^{2}$, Viktor P. Chasovskikh ${ }^{1}$ \\ ${ }^{1}$ Ural State Forest Engineering University Sibirskii trakt str., 37, Yekaterinburg, 620100 Russian Federation \\ ${ }^{2}$ Botanical Garden, Russian Academy of Sciences, Ural Branch, 8 Marta str., 202a, Yekaterinburg, 620144 Russian Federation \\ ${ }^{3}$ Technical University in Zvolen, Faculty of Forestry, T. G. Masaryka 24, SK-960 01 Zvolen, Slovak Republic \\ ${ }^{4}$ Czech University of Life Sciences Prague, Faculty of Forestry and Wood Sciences, Kamýcká 129, \\ CZ-165 21 Praha 6 - Suchdol, Czech Republic \\ ${ }^{5}$ National Forest Centre - Forest Research Institute Zvolen, T. G. Masaryka 2175/22, SK - 96001 Zvolen, Slovak Republic
}

\begin{abstract}
Climate change, especially modified courses of temperature and precipitation, has a significant impact on forest functioning and productivity. Moreover, some alterations in tree biomass allocation (e.g. root to shoot ratio, foliage to wood parts) might be expected in these changing ecological conditions. Therefore, we attempted to model fir stand biomass $\left(\mathrm{t} \mathrm{ha}^{-1}\right)$ along the trans-Eurasian hydrothermal gradients using the data from 272 forest stands. The model outputs suggested that all biomass components, except for the crown mass, change in a common pattern, but in different ratios. Specifically, in the range of mean January temperature and precipitation of $-30^{\circ} \mathrm{C}$ to $+10^{\circ} \mathrm{C}$ and 300 to $900 \mathrm{~mm}$, fir stand biomass increases with both increasing temperature and precipitation. Under an assumed increase of January temperature by $1^{\circ} \mathrm{C}$, biomass of roots and of all components of the aboveground biomass of fir stands increased (under the assumption that the precipitation level did not change). Similarly, an assumed increase in precipitation by $100 \mathrm{~mm}$ resulted in the increased biomass of roots and of all aboveground components. We conclude that fir seems to be a perspective taxon from the point of its productive properties in the ongoing process of climate change.
\end{abstract}

Key words: fir forests; stand biomass; regression models; additive biomass equations; hydrothermal indices

Editor: Martin Lukac

\section{Introduction}

Since 1850 , the amount of greenhouse gases in the atmosphere has doubled, threatening the planet with catastrophic climate change (Fatichi et al. 2019). At the UN climate summit in Paris in December 2015, 196 countries committed to reducing $\mathrm{CO}_{2}$ emissions and preventing mean global temperature from rising by more than $2^{\circ} \mathrm{C}$ by the end of the century. Forest ecosystems, as sinks of atmospheric carbon, play an important role in this perspective. The ability of forests to sequester atmospheric carbon and to produce organic matter represents the basis of their functioning (Dylis 1978). The concentration of $\mathrm{CO}_{2}$ in the atmosphere can be reduced by increasing carbon stock in the vegetative cover by effective forest management. On the other hand, climate change has a significant impact on vegetation productivity, which in turn affects cycling of organic matter and gas exchange in the biosphere (Golubyatnikov \& Denisenko 2009).

Key data describing the quantitative characteristics of world forests are needed for a global quantitative description of natural and social phenomena (including biosphere functions of forest cover), the scientific community therefore needs to respond to the onset of the Big Data Era (Kudyba et al. 2014). In recent years, scientists from a number of countries have created unified global databases of empirical data and have derived general patterns describing fundamental functions of forest cover. To deepen our understanding of global forest ecosystems, the preference for large-scale synthesis of environmental data and modern digital learning methods is becoming increasingly apparent (Crowther et al. 2015; Poorter et al. 2015; Liang et al. 2016; Lockers et al. 2016; Jucker et al. 2017; Bohn \& Huth 2017).

Temperature and precipitation are the key climatic factors that determine not only the radial growth of 
tree stems, but also forest stand productivity as a whole (DeLucia et al. 2000; Ni et al. 2001; Stegen et al. 2011; D’Aprile et al. 2015; Fang et al. 2016). Numerous studies of stochastic relationships of stand productivity with temperature and precipitation have been carried out at a regional level without accounting for stand age and morphology, and at a global level with or without taking species composition into account (Lieth 1974; Anderson et al. 2006; Keeling \& Phillips 2007; Huston \& Wolverton 2009). The analysis of the results from such studies revealed significant contradictions and uncertainties associated with the assessment of the dependence of these indices on temperature and precipitation using either empirical or functional models (Eggers et al. 2008; Shuman \& Shugart 2009; Poudel et al. 2011; Han et al. 2018). Contradictory results were obtained even within the same region (Eggers et al. 2008; Shuman \& Shugart 2009; Poudel et al. 2011; Han et al. 2018). Moreover, the influence of the climatic factors on biomass production of certain tree species (genera) along Trans-Eurasian climatic gradients of temperature and precipitation is still unknown, since the underlying information is fragmentary or contradictory (Wilmking et al. 2004; Stegen et al. 2011; Fu et al. 2017).

Fir (Abies spp.) is a genus comprising about 50 species of evergreen coniferous trees belonging to the Pinaceae family. They frequently occur in Eurasia, North and Central America, and North Africa, mainly in the mountainous regions. Under the Eurasian conditions, the most frequent Abies species are: A. alba Mill., A. sibirica L., A. nephrolepis Maxim., A. nordmanniana Spach., A. spectabilis (D. Don.) Mirb., and A. sachalinensis (F. Schmidt) Mast., A. veitchii Lindl., A. firma Sieb. et Zucc. In the European territory, Abies alba has been the most frequently studied species of this genus (e.g. Barbu \& Barbu 2005; Savill et al. 2016). Recent research has shown that although Abies alba is much less significant economically than Picea abies L. Karst and Pinus sylvestris L. (both are most common coniferous trees), it might just be the species with the best future perspective under the ongoing climate change (Lindner et al. 2008). The latest work (Bosela et al. 2018) has shown that $A$. alba has a great productive potential, which has recently improved due to the reduction of acid deposition in Central Europe.

When constructing and using allometric models of tree biomass the principle of additivity need to be accounted for (Jacobs \& Cunia 1980). Additivity of biomass components means that the resulting sum of biomass estimates of individual tree components (stems, branches, foliage, roots) obtained from component equations is equal to the value of the total biomass obtained from a general equation for the whole tree (Young et al. 1964). An analysis performed by Sanquetta et al. (2015) showed that additivity of biomass components is not ensured in $80 \%$ of derived models, mainly due to the complexity of statistical analyses and the inaccessibility of adequate modern software (Bi et al. 2004).
The first attempts to implement the principle of additivity were performed in the late 1960s and early 1970 s on the examples of linear biomass models (Kurucz 1969; Kozak 1970). They were followed by the transition to additive systems of nonlinear equations, which are more suitable for accurate biomass quantification, but their computational algorithms are much more complex. One of recent developments is a two-step nonlinear seemingly unrelated regression (Parresol 2001; Dong et al. 2016). The statistical accuracy and, accordingly, the complexity of the calculation algorithms, was consistently increasing as such models were developed, and therefore modern software tools were required. All aforementioned additive systems of equations use an "aggregation" method based on the principle "from the particular (i.e. from component equations) to the general".

Recently, a disaggregation method of proportional weighing based on the principle "from general to particular" was proposed and developed as an alternative to the above-mentioned approach. It has been implemented in two versions: as two-step (Zheng et al. 2015) and threestep (Dong et al. 2015) additive systems of disaggregated equations. The first of them has been applied to aboveground biomass, while the second to total tree biomass, i.e. both aboveground and underground parts.

To date, the influence of climate change on biomass of tree species has not been studied by a systematic application of additive models in accordance to transcontinental hydrothermal gradients. Hence, the purpose of this study was to develop an additive model of biomass estimation of fir stands along the Trans-Eurasian gradients of mean January temperatures and precipitation. The Eurasian database of biomass in trees and individual tree components compiled by Usoltsev (see works: Usoltsev 2010, 2013 for more details) makes it possible to perform an analysis of biological productivity (eventually for both biomass and carbon) at a trans-continental level. The variation range of mean temperatures and precipitation in Eurasia is large and covers a spectrum of natural ecosystems. We hypothesise that the biomass structure of fir stands may be described by an additive system of equations based on two hydrothermal indices - mean January temperature and mean annual precipitation all over Eurasia (i.e. under a wide range of variation of hydrothermal indices). We decided to use the mean January temperature, because warming is most pronounced in the cold half of the year (Golubyatnikov \& Denisenko 2009; Laing \& Binyamin 2013; Felton et al. 2016) and also because winter temperature was found decisive for fir growth (Schwarz 1899; Bijak 2010; Toromani \& Bojaxhi 2010).

\section{Material and methods}

A database describing biomass of forest-forming species of Eurasia (Usoltsev 2010, 2013), consisting of 
data about the whole tree biomass and individual tree components published by a large number of authors, was used in this study. From this database, 272 sampling sites with the biomass data of fir forest stands were selected (Table 1, Fig. 1 and Fig. 2). At each site, several sample trees were selected for biomass sampling of individual tree components. In general, 5 to 10 trees were sampled from each site with the exception of 23 sites established in the Carpathians (Lakida \& Domashovets 2009), from which only $3-4$ trees per site were harvested and processed. From the sample trees, biomass samples were taken from every tree component to determine the dry matter content, and tissue density for wood and bark of stems. Individual biomass components are not equally presented in the database since not all components were determined at each site. Hence, the mass of stems above bark and needles was quantified for all 272 sites, while the mass of branches, stem bark and roots only for 255 , 151 , and 66 sites, respectively.

Sampling procedures for estimating biomass of tree components differed between the studies, since they were performed by representatives of different scientific fields in forestry. However, these small methodological differences do not play the determining role in the level of accuracy of biomass estimates, because there is only one definite variant of biomass component structure corresponding to a given morphological structure of a tree stand (Usoltsev 2007).

The matrix of biomass data representing individual components and forest stand characteristics was assessed against the main driver variables of mean January temperature (Fig. 1) and precipitation (Fig. 2) taken from World Weather Maps (2007). It is known that the effectiveness of modelling of biological communities (of which a forest is the most complex one) depends on the implementation level of a meaningful analysis of the initial data, i.e. on a studied level of the structure of the impact of factors on an object, changing in time and space. To ensure the maximum stability of the model, each of the selected independent variables should be presented in the maximum range of its variation (Usoltsev 2004). In our case, mean January temperatures range from $-40^{\circ} \mathrm{C}$ in the forest-tundra of the North-Eastern Siberia to $+15^{\circ} \mathrm{C}$ in the subtropics of Nepal, and mean annual precipitation from $190 \mathrm{~mm}$ in the permafrost regions of North-Eastern Siberia and the steppe zone of Eurasia to $1,140 \mathrm{~mm}$ in the territory of Nepal.

The matrix containing biomass data, stand variables, and climate characteristics was used as a source of data for the subsequent regression analysis to derive equations for estimation of total biomass and its components. Forest biomass was described using a power function, which belongs to the most widely used functions for such purposes (Picard et al. 2012). When choosing independent variables of the regression model, we adhered to the concept that there is only one definite variant of stand biomass structure corresponding to a given set of taxonometric parameters describing a forest stand (Usoltsev, 2007). The initial structure of the model included the main mass-forming factors of stands - age, stem volume, tree density, mean diameter and mean height. Mean diameter correlated with tree density and mean height correlated with age. Hence, they were excluded in the process of the regression analysis. The synergism $(\ln \mathrm{A}) \cdot(\ln \mathrm{N})$ was introduced in the model to account for the decrease in tree density with age and its effect on the

Table 1. List of 272 sites with biomass data representing Abies spp. used for the construction of additive models.

\begin{tabular}{|c|c|c|c|c|c|c|c|c|c|}
\hline \multirow[b]{2}{*}{ Country } & \multicolumn{2}{|c|}{ Species of Abies } & \multirow[b]{2}{*}{$\begin{array}{l}\text { Number } \\
\text { of } \\
\text { sampling } \\
\text { sites }\end{array}$} & \multicolumn{5}{|c|}{ Range of } & \multirow[b]{2}{*}{ References } \\
\hline & $\begin{array}{l}\text { English } \\
\text { name }\end{array}$ & Latin name & & $\begin{array}{c}\text { Age } \\
\text { [years] }\end{array}$ & $\begin{array}{c}\text { Tree } \\
\text { density } \\
{\left[\mathrm{pcs} \mathrm{ha}^{-1}\right]}\end{array}$ & $\begin{array}{l}\text { Stand } \\
\text { volume } \\
{\left[\mathrm{m}^{3} \mathrm{ha}^{-1}\right]}\end{array}$ & $\begin{array}{l}\text { Above } \\
\text { ground } \\
\text { biomass } \\
\left.\text { tha }^{-1}\right]\end{array}$ & $\begin{array}{l}\text { Root } \\
\text { biomass } \\
{\left[\mathrm{tha}^{-1}\right]}\end{array}$ & \\
\hline Italy & Silver fir & A. alba Mill. & 16 & $20-95$ & $512-2548$ & $173-1095$ & $86-467$ & $\begin{array}{c}\text { Not } \\
\text { available }\end{array}$ & Cantiani 1974; Hellrigl 1974 \\
\hline Romania & Silver fir & A. alba Mill. & 1 & 110 & 485 & 1000 & 470 & $\begin{array}{c}\text { Not } \\
\text { available }\end{array}$ & DeAngelis 1981 \\
\hline $\begin{array}{l}\text { Czech } \\
\text { Republic }\end{array}$ & Silver fir & A. alba Mill. & 1 & 51 & 1667 & 216 & 119 & 15 & Vyskot 1972,1973 \\
\hline Ukraine & Silver fir & A. alba Mill. & 46 & $6-99$ & $223-7400$ & $12-770$ & $14-326$ & $6-60$ & Odinak et al. 1986; Lakida and Domashovets 2009 \\
\hline \multirow{3}{*}{ Russia } & Siberian fir & A. sibirica L. & 142 & $20-200$ & $165-54080$ & $30-540$ & $17-212$ & $8-48$ & $\begin{array}{l}\text { Khanbekov 1972; Krauklis et al. 1975; Kuzikov 1979; } \\
\text { Onuchin \& Borisov 1983; Mitrofanov et al. 1986; } \\
\text { Usoltsev \& Antropov, 2001; Andriyanova 2001; } \\
\text { Koshurnikova 2007; Usoltsev et al. } 2012\end{array}$ \\
\hline & Khingam fir & $\begin{array}{l}\text { A. nephrolepis } \\
\text { Maxim. }\end{array}$ & 11 & $41-192$ & $587-5125$ & $68-383$ & 40-189 & $38-51$ & Dyukarev \& Rozenberg 1975; Opritova et al. 1982 \\
\hline & Nordmann fir & $\begin{array}{l}\text { A. nordman- } \\
\text { niana Spach. }\end{array}$ & 5 & $160-283$ & $332-544$ & $601-1294$ & $327-598$ & 69-101 & Orlov 1951; Veselov 1973 \\
\hline Nepal & Himalayan fir & $\begin{array}{l}\text { A. spectabilis } \\
\text { (D.Don) Mirb. }\end{array}$ & 6 & 100 & $275-1450$ & $336-758$ & $158-417$ & $38-102$ & Yoda 1967,1968 \\
\hline \multirow{3}{*}{ Japan } & Todo-fir & $\begin{array}{l}\text { A. sachalinen- } \\
\text { sis (F.Schmidt) } \\
\text { Mast. }\end{array}$ & 7 & $8-35$ & $1178-2870$ & $1-321$ & $1-196$ & $\begin{array}{c}\text { Not } \\
\text { available }\end{array}$ & Yamamoto \& Sanada 1970; Satoo 1973; Ueda 1974; \\
\hline & Veitch's fir & $\begin{array}{l}\text { A. veitchii } \\
\text { Lindl. }\end{array}$ & 26 & $13-126$ & $1204-19500$ & $114-568$ & $68-257$ & $4-62$ & \multirow{2}{*}{$\begin{array}{l}\text { Oshima et al. 1958; Kimura 1963; Oohata \& Oniishi } \\
\text { 1974; Tadaki et al. } 1977 \\
\text { Furuno \& Kawanabe 1967; Ando et al. 1977; Furuno } \\
\text { et al. } 1979\end{array}$} \\
\hline & Momi-fir & $\begin{array}{l}\text { A. firma Sieb. } \\
\text { et Zucc. }\end{array}$ & 11 & 120 & $353-1250$ & $157-930$ & $90-502$ & 145 & \\
\hline
\end{tabular}




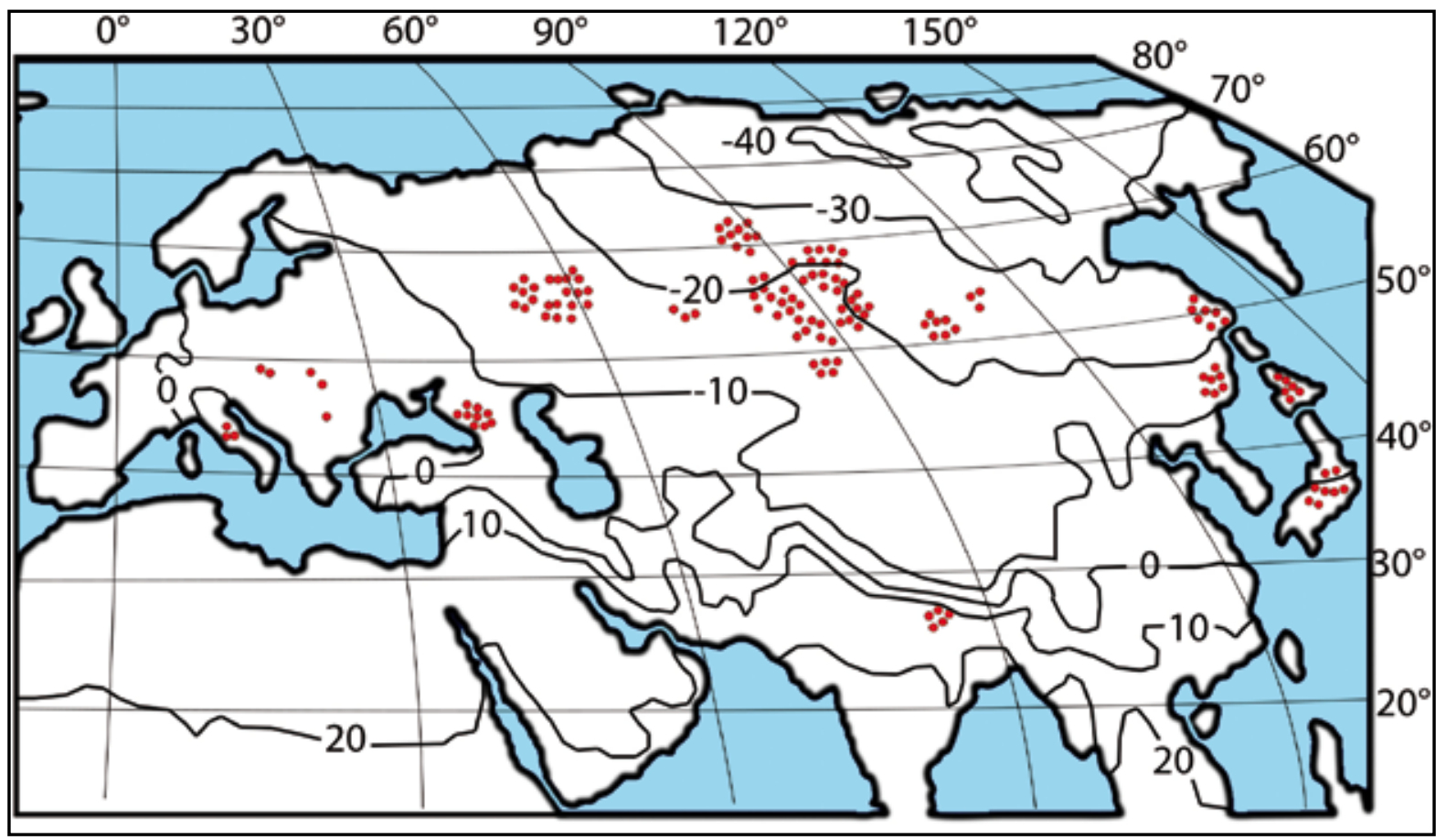

Fig. 1. Location of 272 Abies spp. for biomass sampling sites (in most cases biomass was determined specifically for each tree component; i.e. needles, branches, stem bark, stem wood, and roots) with regard to the mean January temperature $\left[{ }^{\circ} \mathrm{C}\right]$ (source: World Weather Maps 2007; see also https://store.mapsofworld.com/image/cache/data/map_2014/currents-andtemperature-jan-enlarge-900x700.jpg).

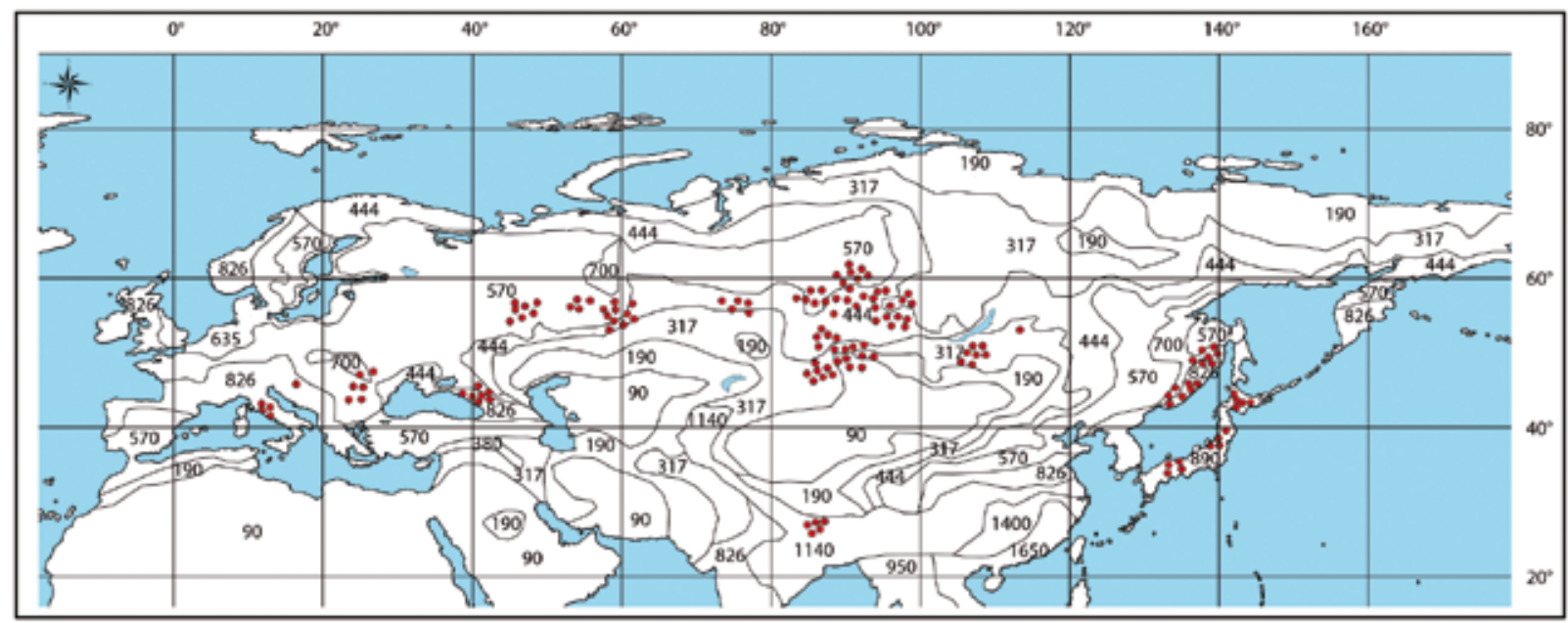

Fig. 2. Location of 272 Abies spp. biomass sampling sites (in most cases biomass was determined specifically for each tree component; i.e. needles, branches, stem bark, stem wood, and roots) with regard to the mean annual precipitation [mm] (source: World Weather Maps 2007; see also http://www.mapmost.com/world-precipitation-map/free-world-precipitation-map/).

stand biomass. In addition, the climate characteristics, namely mean January temperature and annual precipitation total, were included in the model to account for the impact of environmental conditions. The final model included only those variables that were found significant for all biomass components. Hence, the general regression equation was:

$$
\begin{aligned}
& \ln P_{i}=a_{0 i}+a_{1 i}(\ln A)+a_{2 i}(\ln V)+a_{3 i}(\ln A) \cdot(\ln N) \\
& a_{4 i}[\ln (T m+40)]+a_{5 i}(\ln P R m)+a_{6 i}[\ln (T m+40)] \\
& \cdot(\ln P R m)
\end{aligned}
$$

where $P$ is biomass of $i^{\text {th }}$ component, t per ha; $A$ is stand age, yrs; $V$ is stand stem volume above bark, $\mathrm{m}^{3}$ per ha; $N$ is tree number, 1000 per ha; $i$ is index of biomass components as follows: total $(t)$, aboveground $(a)$, roots $(r)$, crown $(c)$, stem above bark $(s)$, foliage $(f)$, branches $(b)$, stem wood $(w)$, and stem bark $(b k)$; $P R m$ is mean annual precipitation total, $\mathrm{mm}$; $T m$ is mean January temperature, ${ }^{\circ} \mathrm{C}$. Since the mean January temperature at the northern limit of Eurasia is negative (Fig. 2), the corresponding independent variable was increased by $40(\mathrm{Tm}+40)$ to enable a logarithmic transformation according to Baskerville (1972). The problem of transforming the model (1) into a tabular form 
is that we can specify only stand age, temperature, and precipitation, while stem volume and tree density can be obtained by a system of auxiliary recursive equations having the general form:

$$
\begin{aligned}
& N=f[A,(T m+40), P R m] \\
& V=f[A, N,(T m+40), P R m]
\end{aligned}
$$

The regression coefficients of multiple regression equations [1], [2], and [3] were calculated using the Statgraphics software (see http://www.statgraphics.com/ for more information).

First, an initial equation for the estimation of the total tree biomass was derived. Then, a three-step additive disaggregation system of equations was applied (e.g. Dong et al. 2015; Zheng et al. 2015). Hence, the total biomass estimated from the initial equation was divided into its constituent parts according to the scheme presented in Fig. 3. In the first step, the total tree biomass was divided into roots and the aboveground part in accordance with their shares in the total biomass represented by the corresponding component equations (step 1). Afterwards, the resulting aboveground biomass was divided in the same way into the crown and the stem above bark (step 2). Finally, the crown biomass was divided into foliage and branches (step 3a), and stem biomass into wood and bark (step 3b) (Fig. 3). Such an algorithm enables the simulation of a component structure of forest stand biomass despite different representation of the components in the total biomass, because their relative proportions are used as a basis instead of absolute values, which minimises the bias of estimates.

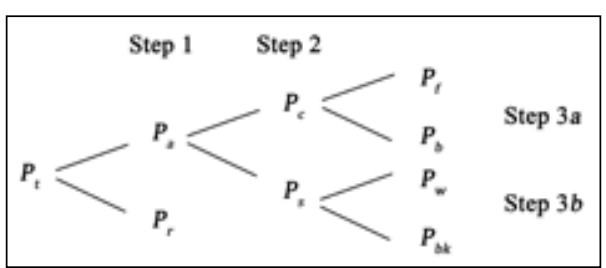

Fig. 3. The pattern of the disaggregating three-step proportional weighting additive model. Designation: $P t, P r$, $P a, P c, P s, P f, P b, P w$ and $P b k$ represent stand biomass in t per ha as follows: total, underground (roots), aboveground, crown (foliage and branches), stems above bark (wood and bark), foliage, branches, stem wood and stem bark, respectively.

\section{Results}

The initial equations after the correction for logarithmic transformation by Baskerville (1972) and anti-log transforming are characterised by the significance level of at most 0.05 (Table 2). The equations represent the biomass data included in the above mentioned database. These equations were modified to the additive form according to the algorithm presented in Fig. 3. As a result, we obtained the final form of the transcontinental additive model of component composition of fir biomass, shown in Table 3.

The comparison of observed biomass with the predicted values using the initial (Table 2) and additive (Table 3 ) equations confirmed the adequacy of the

Table 2. Characteristics of initial models (1) after their anti-log transformation. Designation: $A$ is stand age, yrs; $V$ is stand stem volume above bark, $\mathrm{m}^{3}$ per ha; $N$ is tree number, 1000 per ha; $P R m$ is mean annual precipitation total, $\mathrm{mm} ; \mathrm{Tm}$ is mean January temperature, ${ }^{\circ} \mathrm{C}, \mathrm{P}$ is stand biomass, t per ha, in biomass components as follows: total $(t)$, aboveground $(a)$, roots $(r)$, crown $(c)$, stem above bark $(s)$, foliage $(f)$, branches $(b)$, stem wood $(w)$, and stem bark $(b k)$. The abbreviation $a d j R^{2}$ is a coefficient of determination adjusted for the number of parameters; $S E$ - equation standard error.

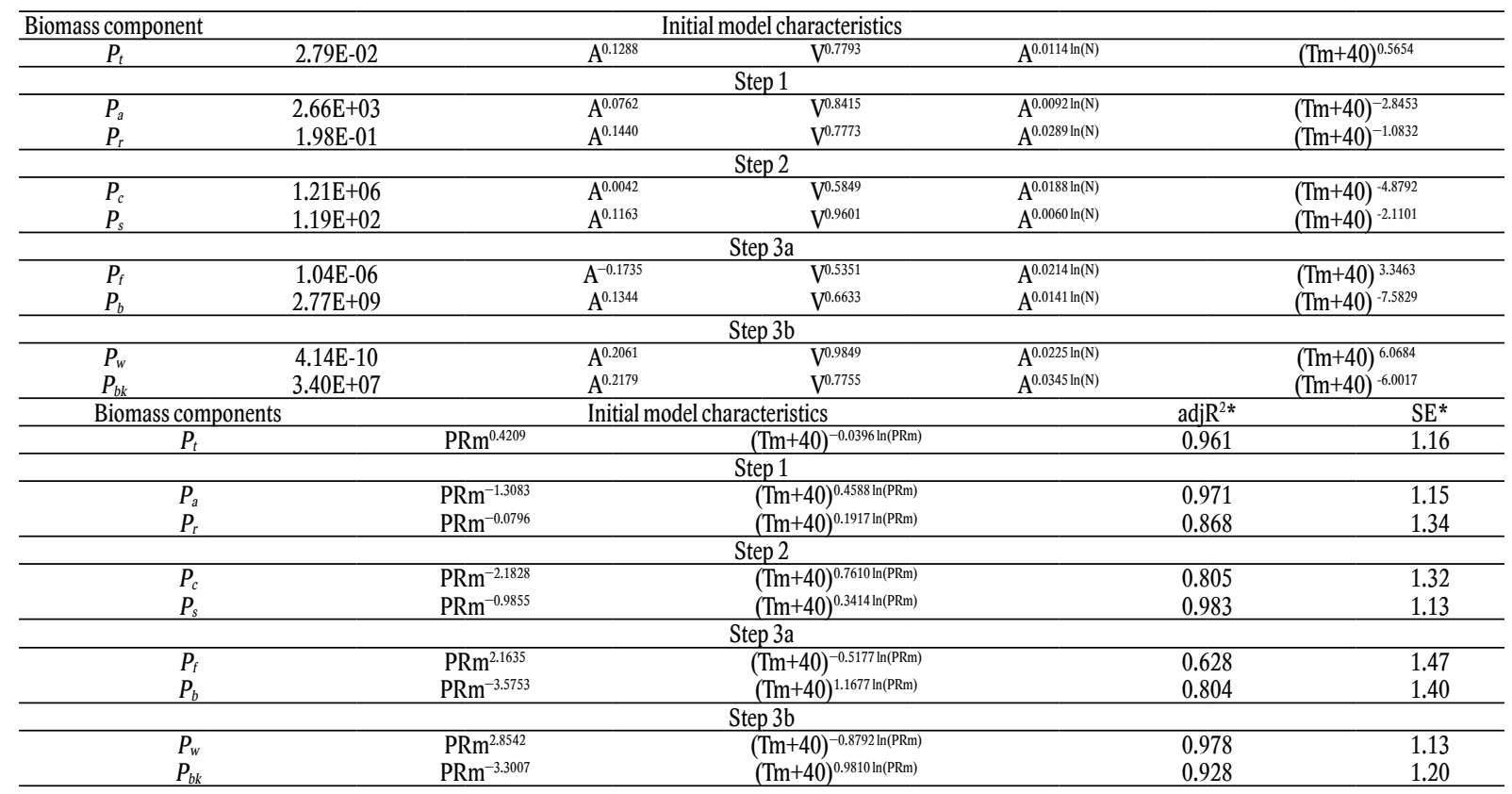


derived models, since they usually explained more than $50 \%$ of variability in biomass depending on the biomass component (Fig. 4). The variability of aboveground and stem biomass was captured well, as our equations explained more than $90 \%$ of observed variance (Fig. 4). High correlation between predicted and observed biomass was also observed for stem wood ( $\mathrm{R}^{2}$ of around 0.8$)$, followed by roots, branches, and crown $\left(\mathrm{R}^{2}\right.$ of around $0.7)$. The model explained the least variability in the biomass of foliage and stem bark (Fig. 4).

The equations [2] and [3] derived from the data on fir stands were significant at a level of 0.05 and explained $68 \%$ and $61 \%$ of variability of number of trees and stand volume per ha, respectively (Table 4). As Fig. 5 shows, the biomass of all components in 100-year-old fir stands grows as mean annual precipitation total and mean January temperature increase.

Under an assumed increase in temperature by $1^{\circ} \mathrm{C}$, the model results showed that more biomass was accumulated in 100-year-old fir stands regardless of precipitation conditions in comparison to current temperature conditions (Fig. 6). Similarly, an increase in precipitation by $100 \mathrm{~mm}$ resulted in the increase in biomass of fir stands under all temperature and precipitation combinations present in this study of Eurasia (Fig. 7). The exceptions were the patterns for the foliage and branches, for which a slight decrease of their biomass was estimated in warm climatic zones $\left(\mathrm{Tm}=10^{\circ} \mathrm{C}\right.$, Fig. 7) regardless of the existing level of precipitation.

\section{Discussion}

Our modelling suggested that biomass of all fir components grows as precipitation total increases from 300 to $900 \mathrm{~mm}$, as well as due to the increase in the mean January temperature from $-30^{\circ} \mathrm{C}$ to $+10^{\circ} \mathrm{C}$ (Fig. 5). The finding is consistent with the increase in relative radial increment of boreal forests in Canada if both mean annual temperature and annual precipitation increase (Miao \& Li 2011). However, this trend does not correspond to the results obtained using similar models for biomass quantification in two-needled pine forests of Eurasia (Usoltsev et al. 2019b). The pine models manifested different trends, since in cold zones $\left(\mathrm{Tm}=-20^{\circ} \mathrm{C}\right)$ precipitation increase leads to a decrease of biomass, while in warm zones $\left(T m=10^{\circ} \mathrm{C}\right)$ to their increase, with the exception of root biomass. Correspondingly, temperature increase in wet areas $(P R m=900 \mathrm{~mm})$ causes an increase of biomass in two-needled pine forests, while in dry areas $(P R m=300$ $\mathrm{mm}$ ) it causes their decrease, with the exception of roots. Derived additive models of fir stand biomass allow us to determine quantitative changes in the biomass structure due to the climate change, in particular, the mean January temperature and mean annual precipitation.

The change in the biomass structure is associated with the changes of these two climatic parameters. For example, if the mean January temperature in the central part of European Russia, characterised by the mean January temperature equal to $-10^{\circ} \mathrm{C}$ and the mean annual precipitation equal to $400 \mathrm{~mm}$ (Fig. 1 and Fig. 2) is increased by $1^{\circ} \mathrm{C}$, the model suggests that the biomass of all compo-

Table 3. Final three-step additive model of Abies forest biomass derived for Eurasia. Designation: $A$ is stand age, yrs; $V$ is stand stem volume above bark, $\mathrm{m}^{3}$ per ha; $N$ is tree number, 1000 per ha; $P R m$ is mean annual precipitation total, mm; $T m$ is mean January temperature, ${ }^{\circ} \mathrm{C}, P$ is stand biomass, $t$ per ha, in biomass components as follows: total $(t)$, aboveground $(a)$, roots $(r)$, crown $(c)$, stem above bark $(s)$, foliage $(f)$, branches $(b)$, stem wood $(w)$, and stem bark $(b k)$.

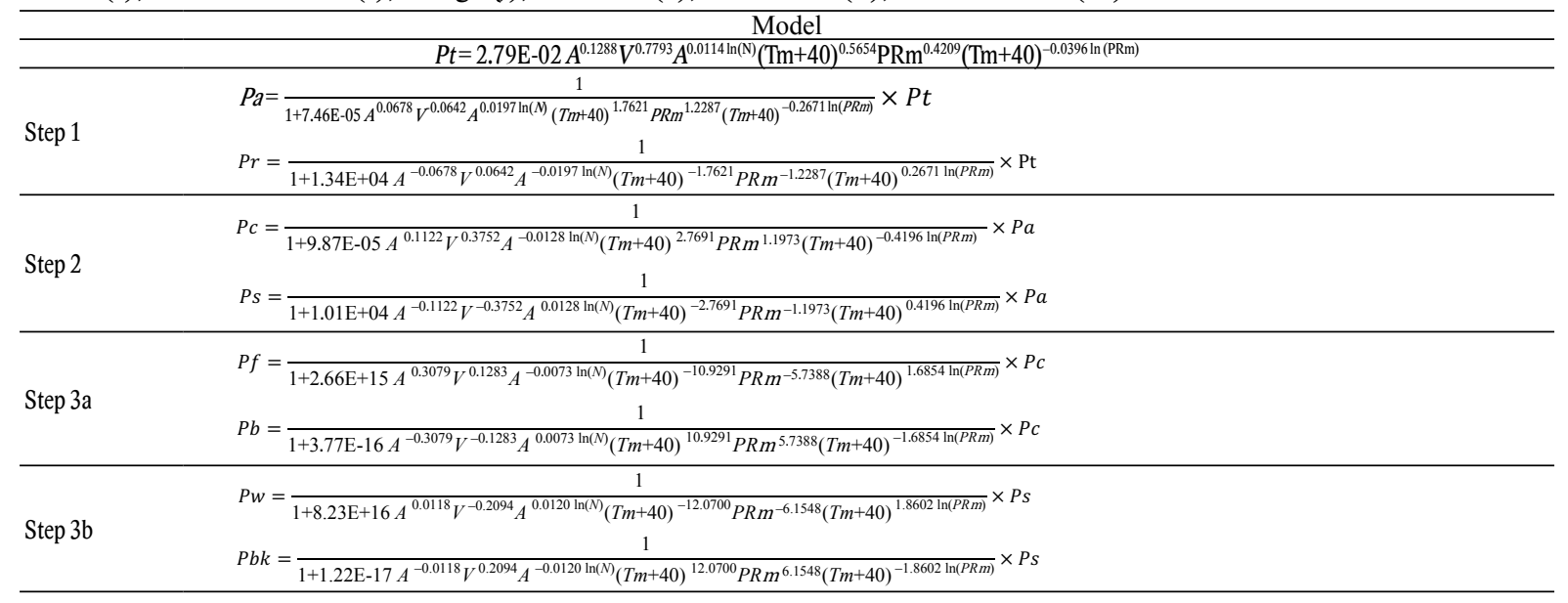

Table 4. Characteristics of the recursive system of auxiliary equations for fir stand characteristics.

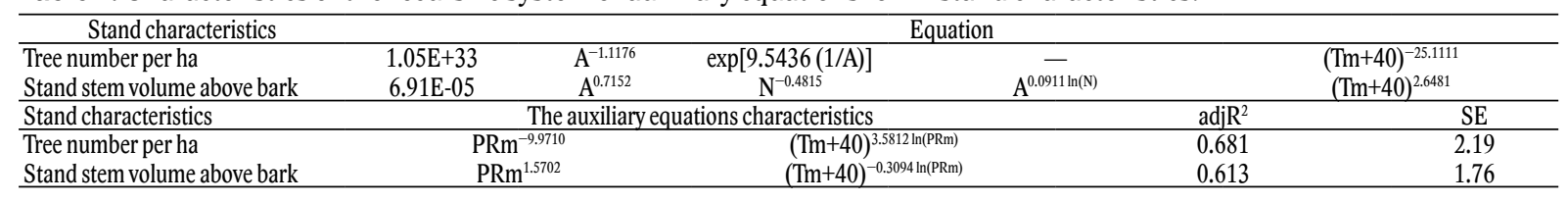




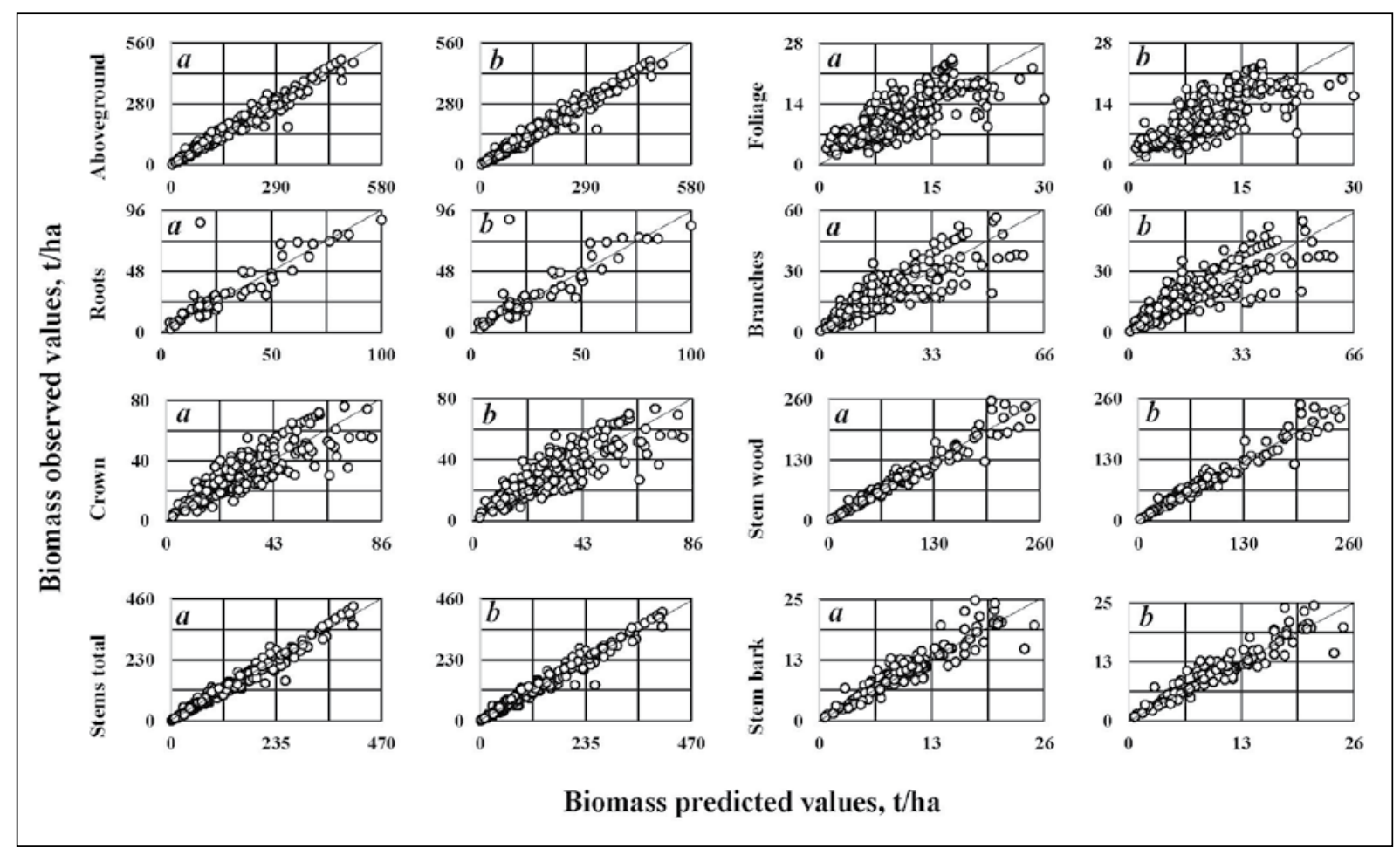

Fig. 4. Observed stand fir biomass plotted against predicted biomass obtained by calculating the initial (a) and additive (b) models.

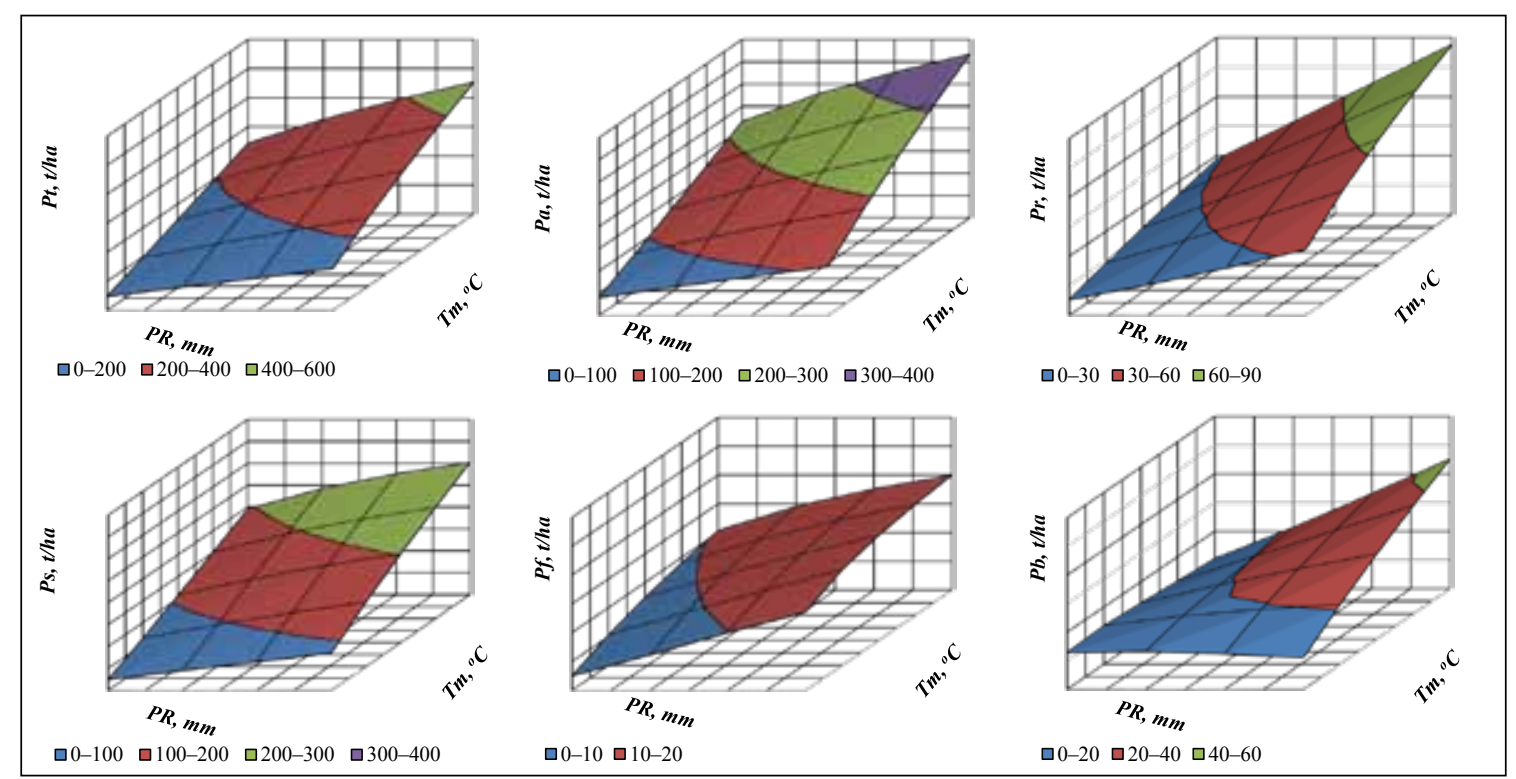

Fig. 5. The dependence of fir stand biomass upon mean January temperature $(\mathrm{Tm})$ and annual precipitation $(P R m)$ at the stand age of 100 years. Designation: $P t, P s, P a, P f, P r$, and $P b$ - total biomass, biomass in stems, aboveground, foliage, roots, and branches, $t$ per ha, respectively. 


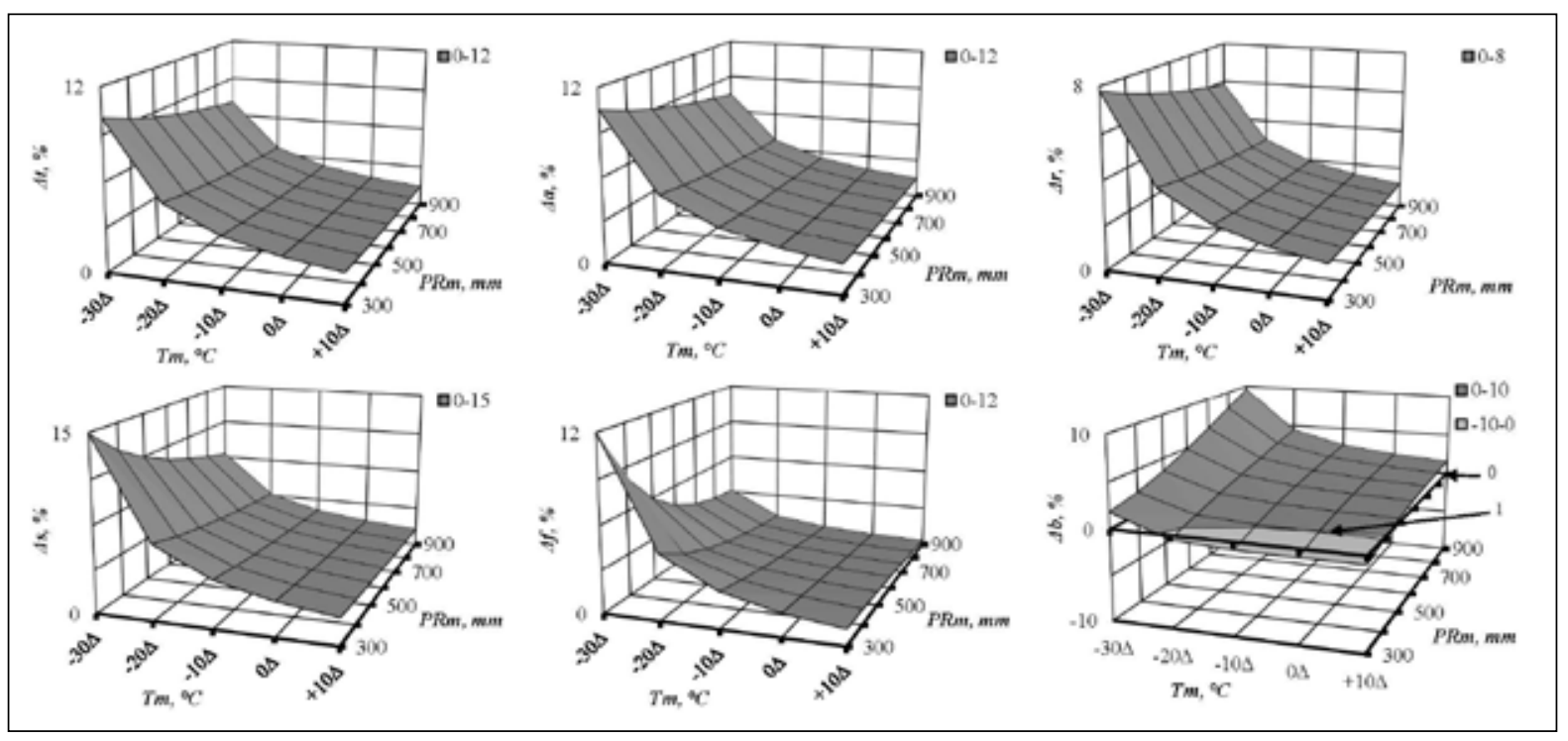

Fig. 6. Simulated changes in fir stand biomass due to the assumed temperature increase of $1^{\circ} \mathrm{C}$ based on the derived model (for the stands aged 100 years). $T m$ - mean January temperature, ${ }^{\circ} \mathrm{C} ; P R m$ - mean annual precipitation, mm. Temperature values on $X$ axis designated as $-30 \Delta \ldots+10 \Delta$ represent the mean January temperature increased by $1^{\circ} \mathrm{C}$. The relative changes in individual biomass components (\%) are marked as follows: total $\Delta P t$, aboveground $\Delta P a$, roots $\Delta P r$, stems $\Delta P s$, foliage $\Delta P f$ and branches $\triangle P b$. The value 0 represents the plane corresponding to zero change of biomass at the expected temperature increase by $1^{\circ} \mathrm{C}$; the value 1 represents the border between positive and negative changes in biomass $(\Delta, \%)$ at the expected temperature increase by $1^{\circ} \mathrm{C}$.

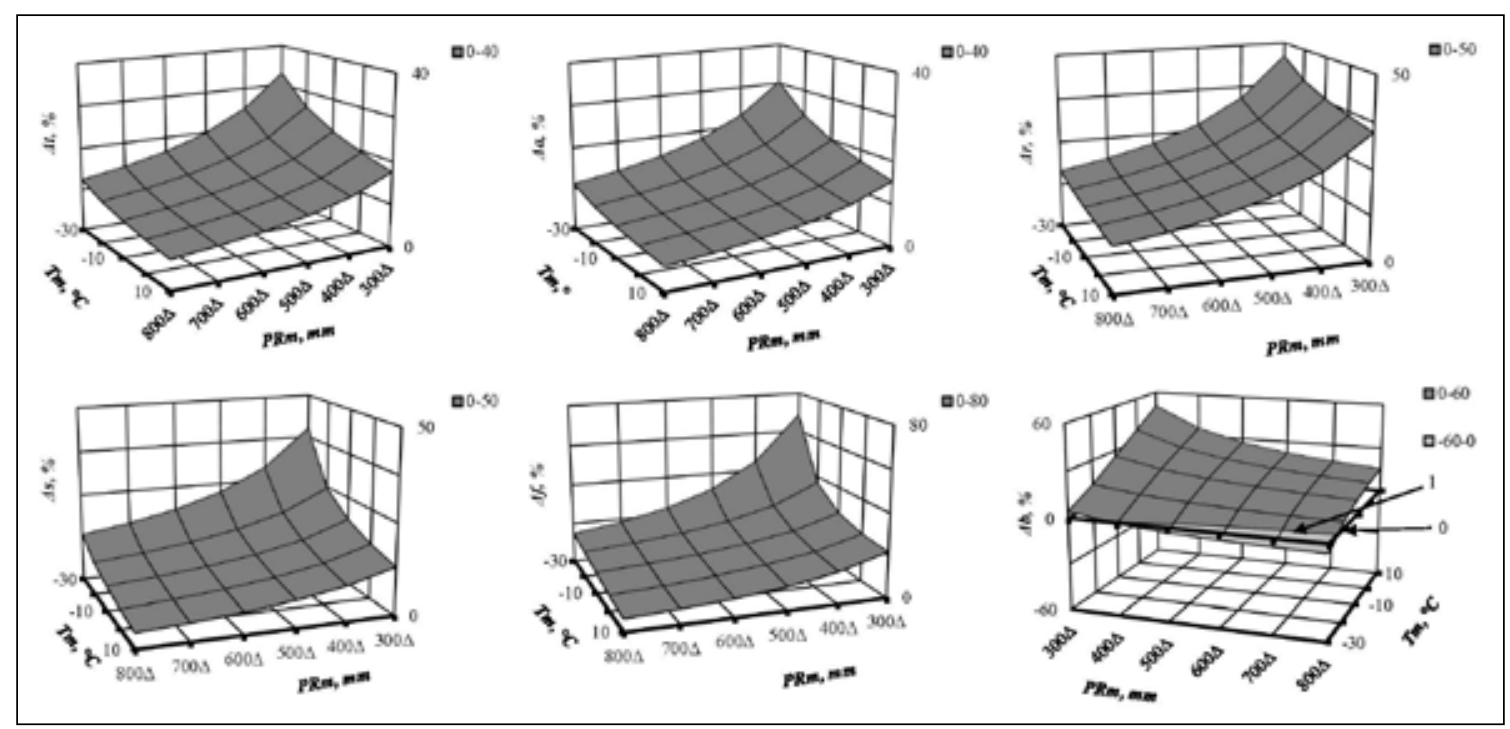

Fig. 7. Simulated changes in fir stand biomass due to the assumed precipitation increase of $100 \mathrm{~mm}$ (for the stands aged 100 years). $T m$ - mean January temperature, ${ }^{\circ} \mathrm{C} ; P R m$ - mean annual precipitation, mm. Precipitation values on $X$ axis designated as $300 \Delta \ldots 800 \Delta$ represent the annual precipitation total increased by $100 \mathrm{~mm}$. The relative changes in individual biomass components (\%) are marked as follows: total $\Delta P t$, aboveground $\Delta P a$, roots $\Delta P r$, stems $\Delta P s$, foliage $\Delta P f$ and branches $\Delta P b$. The value 0 represents the plane corresponding to zero change of biomass at the expected temperature increase by $1^{\circ} \mathrm{C}$; the value 1 represents the border between positive and negative changes in biomass $(\Delta, \%)$ at the expected temperature increase by $1^{\circ} \mathrm{C}$. 
nents in a 100-year-old stand would increase by $3.9,3.8$, $4.6,3.8,4.6$, and $3.5 \%$ in the case of total biomass, aboveground, roots, stems, foliage, and branches, respectively. Similarly, the increase in precipitation by $100 \mathrm{~mm}$ in the same region while keeping mean January temperature constant caused an increase in the total biomass, aboveground, roots, stems, foliage and branches by 12.5, 11.9, $15.3,12.7,1.4$ and $1.9 \%$, respectively. Our results show that both temperature and precipitation increases result in positive trends of biomass accumulation (Fig. 5). The exception is the foliage biomass, which in the warm zone $\left(T m=+10^{\circ} \mathrm{C}\right)$ decreases with increasing precipitation during the transition from the regions of insufficient moisture $(P R m=300 \mathrm{~mm})$ to the regions of increased moisture $(P R m=900 \mathrm{~mm})$.

Here, we would like to point out that not only total quantity of forest stand biomass but also its allocation to individual tree components is important from carbon sequestration point of view. For instance, a ratio between foliage, i.e. a component with fast carbon turnover, and woody parts, i.e. long-run carbon turnover, determines the rate of carbon cycling via tree biomass (e.g. Šebeň et al. 2017). Moreover, the root to shoot ratio describes carbon proportion situated above ground and in the soil. Those two different environments represent contrasting conditions for wood decomposition and carbon emission after tree perishes (e.g. Laiho \& Prescott 2004).

It is generally known that the efficiency of environmental object modelling depends on the level of implementation of a meaningful analysis of empirical data, i.e. on the studied level of impact factors changing in time and space. In relation to a single factor, this principle means identifying the most informative (active) range of its effects (Liepa 1980) in order to identify the optimal range within which the selected factor, ambiguous in its informativeness, would explain the largest proportion of variability of the resulting variable. Our study uses the winter temperature index as the most sensitive to climate change, and one can draw an analogy with a similar process at a global level: the temperature at the Earth poles increases at an accelerated rate compared to the mainland (Henderson 2006). In the future, the impact of temperatures representing different parts of the year should be tested and the most significant period should be used in the models.

Presented approach of biomass calculation ensures that the sum of component biomass amounts obtained from component equations is equal to the value of the total biomass calculated with the general equation. Two algorithms have been proposed for this purpose: (1) an "aggregation" method based on the principle "from the particular (i.e. from component equations) to the general" (Parresol 2001), and (2) a “disaggregation" method of proportional weighing based on the principle "from general to particular" (Dong et al. 2015). When comparing aggregation and disaggregation methods using the data from 122 sample trees, Dong et al. (2015) concluded that although the results obtained by the two methods were similar, the second one led to a smaller standard error of regression coefficients. An advantage of our chosen disaggregated structure of the model is that it can be used for global or transcontinental modelling, because it uses climate variables as independent input, which cannot be included in the "aggregated" model (Parresol 2001). Another possible approach is to construct a system of regional equations and use dummy variables that specify particular ecoregions (Usoltsev et al. 2019a).

In order to understand possible impacts of climate change on forest biological productivity and to obtain sufficiently adequate simulation results of this relationship, it is necessary to provide empirical data on productivity and climate variables in the widest possible range of their variation, i.e. at global or continental levels. In a recent work (Zeller et al. 2018), geographical coordinates of sample plots, as well as annual precipitation and temperature were included in the model of forest productivity for the territories of Germany and the United States along with main defining independent variables. We contend that the evidence of the authors is contradictory because: (1) climate variables are correlated with geographical coordinates of sample plots in this model, and (2) the ranges of variability of climate variables within a country were too small to obtain stable patterns. To avoid such uncertain results, a transcontinental level of analysis was chosen in our study, and geographical coordinates were not included among independent variables.

The question may arise why modelling was performed at the level of Abies genus, and not for individual fir species. In the world affected by climate change, large-scale analyses are needed as they can provide us with general trends. The spatial distribution of individual Abies species in Eurasia is rather scattered and complementary (Savill et al. 2016), which does not allow for a large-scale analysis of individual species based on the available empirical data. In plant horology, this distribution is known as species substitution, or replacing of species, which occurs in the cases of paleo-geographically protracted dissociation of once continuous plant habitat (Hultén 1937; Tolmachev 1962) or due to the climatologically caused morphogenesis (Chernyshev 1974). A disadvantage of the database used in this study is the uneven spatial distribution of sampling sites over Eurasia (Fig. 2) resulting in different representation of individual ecoregions. Since in the regression analysis of biomass data we used the least squares method, estimates of biomass in ecoregions with a minimum number of sampling sites (Romania and the Czech Republic) may be biased due to the greater "information weight" of ecoregions with the largest numbers of sampling sites (Central Siberia and China). Methodological uncertainties causing biases in biomass amounts in individual tree parts may also affect the accuracy of the estimates. This applies primarily to the underground biomass. The analysis of the world data of underground tree biomass has showed that due to the 
imperfection of methods to estimate fine root biomass, the total underground biomass of stands may be underestimated two to five times (Usoltsev 2018).

As is usually the case, the solution of each new problem and the corresponding removal of the associated uncertainty generates several new ones. In our case, two main uncertainties have arisen:

1) The patterns of biomass amount change under assumed changed climatic conditions (Fig. 6 and Fig. 7) are hypothetical. They reflect long-term adaptive responses of forest stands to regional climatic conditions and do not take into account rapid trends of current environmental changes, which place serious constraints on the ability of forests to adapt to new climatic conditions (Alcamo et al. 2007).

2) The presented patterns are related to fir forests, which are either pure or with a slight admixture of other tree species. However, fir usually grows in mixed stands (Bosela et al. 2018). There is a body of evidence that mixed stands are more resistant to stress caused by abiotic factors and are more productive than pure stands (Liang et al. 2016). However, a recent study of net primary production (NPP) of aboveground biomass from forests in Spain and Canada over a wide range of biodiversity index values as well as of mean temperature and moisture conditions (Paquette et al. 2018) led to a paradoxical conclusion. The authors found that in pure forest stands (low value of biodiversity index), NPP reacts to temperature rise of $1-2^{\circ} \mathrm{C}$ in different climatic zones in different ways: it grows in temperate forests, remains stable in boreal forests and declines in the Mediterranean forests. However, as the biodiversity index increases, these trends gradually transform into a unified negative trend, common for all zones (Paquette et al. 2018). This result indicates that the revealed trajectories of changes in biomass and NPP of pure (or almost pure) forest communities may not hold under the conditions of variable climate: in forests with an increased biodiversity index, the patterns can be significantly modified and even reversed.

Taking into account the stated methodological and conceptual uncertainties, the results presented in this study should be considered as preliminary ones. They can be modified if the biomass database will be enlarged by additional data, mainly site-specific and stand-specific characteristics. Moreover, further inherent phenomena of climate change (especially $\mathrm{CO}_{2}$ concentration in the atmosphere) could be potentially included in future models if the corresponding data were available.

\section{Conclusion}

This paper presents a model for calculating stand biomass of fir species along the trans-Eurasian hydrothermal gradient. The model was derived from the biomass data of nearly 300 fir stands and climate data. We revealed that all biomass components of examined stands changed in the same direction: fir stand biomass increased with the increasing precipitation within the evaluated range from 300 to $900 \mathrm{~mm}$ per year, as well as due to the increase in the mean January temperature from $-30^{\circ} \mathrm{C}$ to $+10^{\circ} \mathrm{C}$ regardless of the precipitation level. A modelled increase of January temperature by $1^{\circ} \mathrm{C}$, or of precipitation by 100 $\mathrm{mm}$, caused an increase in biomass of all components of fir stands. Our results indicate that fir would not suffer from the projected climate change. However, from the long-term perspective, climate change might bring even more drastic modification of winter temperature and annual sum of precipitation than was considered here. Therefore, our outputs represent a reasonable an example of model sensitivity to changing climatic conditions. The development of such models for the main forestforming species of Eurasia allow predicting changes in the productivity of the forest cover of Eurasia in relation to climate change.

\section{Acknowledgements}

This paper was prepared within the programs of the current scientific research of the Ural Forest Engineering University and Botanical Garden of the Ural Branch of Russian Academy of Sciences. This work was supported by grant "EVA4.0", No. CZ. 02.1.01/0.0/0.0/16_019/0000803 financed by OPRDE, by the Slovak Research and Development Agency under contracts No. $A P V V-15-0265, A P V V-16-0325, A P V V-18-0086$ and the Scientific Grant Agency of the Ministry of Education, Science, Research and Sport of the Slovak Republic under contracts No. VEGA 1/0367/16.

\section{References}

Alcamo, J., Moreno, J. M., Nováky, B., Bindi, M., Corobov, R., Devoy, R. J. N. et al., 2007: Europe: impacts, adaptation and vulnerability. Contribution of Working Group II to the Fourth Assessment Report of the Intergovernmental Panel on Climate Change. In: Parry, M. L., Canziani, O. F., Palutikof, J. P., van der Linden, P. J., Hanson, C. E. (eds.): Climate change. Cambridge University Press, Cambridge, p. 541-580.

Anderson, K. J., Allen, A. P., Gillooly, J. F., Brown, J. H., 2006: Temperature-dependence of biomass accumulation rates during secondary succession. Ecology Letters, 9:673-682.

Ando, T., Chiba, K., Nishimura, T., Tanimoto, T., 1977: Temperate fir and hemlock forests in Shikoku. In: Primary productivity in Japanese forests. JIBP Synthesis. University of Tokyo Press, 16:213-245.

Andriyanova, O.V., 2001: Peculiarities of biological cycle of chemical elements in spruce-fir forests at Mari-El republic: Ph. D. Thesis. Ioshkar-Ola, Technical University, $22 \mathrm{p}$.

Barbu, I., Barbu, C., 2005: Silver fir (Abies Alba Mill.) in Romania. Campulung Moldovenesc, Editura Rechnica Silvica, $220 \mathrm{p}$. 
Baskerville, G. L., 1972: Use of logarithmic regression in the estimation of plant biomass. Canadian Journal of Forest Research, 2:49-53.

Bi, H., Turner, J., Lambert, M. J., 2004: Additive biomass equations for native eucalypt forest trees of temperate Australia. Trees, 18:467-479.

Bijak, S., 2010: Tree-ring chronology of silver fir and its dependence on climate of the Kaszubskie Lakeland (Northern Poland) Geochronometria, 35: 91-94.

Bohn, F. J., Huth, A., 2017: The importance of forest structure to biodiversity-productivity relationships. Royal Society Open Science, 4:160521.

Bosela, M., Lukac, M., Castagneri, D., Sedmák, R., Biber, P., Carrer, P. et al., 2018: Contrasting effects of environmental change on the radial growth of cooccurring beech and fir trees across Europe. Science of the Total Environment, 615:1460-1469.

Cantiani, M., 1974: Tavola di produttivita della biomassa arborea. In: Ricerche Sperimentale di Dendrometria e di Auxometria. Fascicolo V. Prime indagini sulla biomassa dell' abete bianco. Instituto di Assestamento Forestale, Facolta di Agraria, Universita degli studi di Firenze, p. 41-57.

Chernyshev, V. D., 1974: Pathways of physiological and energetic adaptations of conifers under extreme conditions. In: Biologicheskie problemy Severa: Tezisy VI Simp. (Biological Problems of the North: Abstr. VI Symp). Yakutsk: Inst. Biol., Yakutsk. Fil. Sib. Otd. Akad. Nauk SSSR, 5:13-17.

Crowther, T. W., Glick, H. B., Covey, K. R., Bettigole, C., Maynard, D. S., Thomas, S. M. et al., 2015: Mapping tree density at a global scale. Nature, 525:201-205.

D’Aprile, F., Tapper, N., Marchetti, M., 2015: Forestry under climate change. Is time a tool for sustainable forest management? Open Journal of Forestry, 5:329-336.

DeAngelis, D. L., Gardner, R. H., Shugart, H. H., 1981: Productivity of forest ecosystems studied during the IBP: The woodlands data set In: Reichle, D. E. (ed.). Dynamic properties of forest ecosystems. IBP-23. Cambridge, University Press, p. 567-672.

DeLucia, E. H., Maherali, H., Carey, E.V., 2000: Climatedriven changes in biomass allocation in pines. Global Change Biology, 6:587-593.

Dong, L., Zhang, L., Li, F., 2015: A three-step proportional weighting system of nonlinear biomass equations. Forest Science, 61:35-45.

Dong, L., Zhang, L., Li, F., 2016: Developing two additive biomass equations for three coniferous plantation species in Northeast China. Forests, 7:36.

Dylis, N. V., 1978: Fundamentals of biogeocenology. Moscow, Moscow State University Publ., 152 p.

Dyukarev, V. N., Rozenberg, V.A., 1975: Above-ground phytomass of stands, ingrowth and bushwood in fir and spruce forests of Sikhote-Alin' Mountain In: Proc. of Biology and Soil Institute, 136:30-50.
Eggers, J., Lindner, M., Zudin, S., Zaehle, S., Liski, J., 2008: Impact of changing wood demand, climate and land use on European forest resources and carbon stocks during the 21st century. Global Change Biology, 14:2288-2303.

Fang, O., Yang Wang, Y., Shao, X., 2016: The effect of climate on the net primary productivity (NPP) of Pinus koraiensis in the Changbai Mountains over the past 50 years. Trees, 30:281-294.

Fatichi, S., Pappas, C., Zscheischler, J., Leuzinger, S., 2019: Modelling carbon sources and sinks in terrestrial vegetation. New Phytologist, 221:652-668.

Felton, A., Nilsson, U., Sonesson, J., Felton, A. M., Roberge, J.-M., Ranius, T. et al., 2016: Replacing monocultures with mixed-species stands: Ecosystem service implications of two production forest alternatives in Sweden. Ambio, 45 (Supplement 2):124-139.

Fu, L., Lei, X., Hu, Z., Zeng, W., Tang, Sh., Marshall, P. et al., 2017: Integrating regional climate change into allometric equations for estimating tree aboveground biomass of Masson pine in China. Annals of Forest Science, 74:1-15.

Furuno, T., Kawanabe, S., 1967: Investigations on the productivity of Japanese fir (Abies firma Sieb. et Zucc.) and hemlock (Tsuga sieboldii Carr.) stands in Kyoto University Forest in Wakayama. I. On the growth of Japanese fir stands. Bulletin of Kyoto University Forest, 39:9-26.

Furuno, T., Uenishi, S., Uenishi, K., 1979: Investigations on the productivity of Japanese fir (Abies firma Sieb. et Zucc.) and hemlock (Tsuga sieboldii Carr.) stands in Kyoto University Forest in Wakayama. V. Biomass of upperground parts and litterfall in firhemlock stands. Bulletin of Kyoto University Forest, 51:58-70.

Golubyatnikov, L. L., Denisenko, E. A., 2009: Influence of climatic changes on the vegetation of European Russia. News of Russian Academy of Sciences. Geographic Series, 2:57-68.

Han, S. H., Kim, S., Li, G., Chang, H., Yun, S. J., Jiae, A. J., Son, Y., 2018: Effects of warming and precipitation manipulation on fine root dynamics of Pinus densiflora Sieb. et Zucc. Seedlings. Forests, 9:141-12.

Hellrigl, B., 1974: Relazioni e tavole della biomassa arborea. In: Ricerche Sperimentale di Dendrometria e di Auxometria. Fascicolo V. Prime indagini sulla biomassa dell'abete bianco. Instituto di Assestamento Forestale, Facolta di Agraria, Universita degli studi di Firenze, Florence, p. 1-40.

Henderson, M., 2006: Antarctic air is warming faster than rest of world. The Times, Avaiable at: <https:// www.newsru.com/world/31mar2006/ant.html>

Hultén, E., 1937: Outline of the history of arctic and boreal biota during the Quaternary Period. New York, Lehre J. Cramer, 248 p. 
Huston, M. A., Wolverton, S., 2009: The global distribution of net primary production: resolving the paradox. Ecological Monographs, 79:343-377.

Jacobs, M. W., Cunia, T., 1980: Use of dummy variables to harmonize tree biomass tables. Canadian Journal of Forest Research, 10:483-490.

Jucker, T., Caspersen, J., Chave, J., Antin, C., Barbier, N., Bongers, F. et al., 2017: Allometric equations for integrating remote sensing imagery into forest monitoring programmes. Global Change Biology, 23:177-190.

Keeling, H. C., Phillips, O. L., 2007: The global relationship between forest productivity and biomass. Global Ecology and Biogeography, 16:618-631.

Khanbekov, R. I., 1972:Above-ground biomass quantity in dark-coniferous-leaved young forests at Ufimskoye Plateau (Short reports of conference for young scientists). Pushkino, VNIILM, 2:23-29.

Kimura, M., 1963: Dynamics of vegetation in relation to soil development in northern Yatsugataki mountains. Japan. Journal of Botany, 8:255-287.

Koshurnikova, N. N., 2007: Carbon budget in dark-coniferous forests of the southern taiga: Ph. D. Thesis. Krasnoyarsk, V. N. Sukachev Forest Institute, 20 p.

Kozak, A., 1970: Methods of ensuring additivity of biomass components by regression analysis. Forestry Chronicle, 46:402-404.

Krauklis, A. A., Strizhak, T. I., Toporkova, G. P., 1975: Phytomass quantity. In: Natural regimes and topogeo-systems of the taiga near Angara river. Novosibirsk, Nauka, p. 177-200.

Kudyba, S. et al., 2014: Big Data, Mining, and Analytics. Components of Strategic Decision Making. Boca Raton, CRC Press, 288 p.

Kurucz, J., 1969: Component weights of Douglas-fir, western hemlock, and western red cedar biomass for simulation of amount and distribution of forest fuels. University of British Columbia, Forestry Department, PhD thesis, $116 \mathrm{p}$.

Kuzikov, I. E., 1979: Biomass change in fir forests of Hylocomiosum type in different climatic conditions of the Middle Siberia: Ph.D. thesis. Krasnoyarsk, Siberian Technological Institute, $24 \mathrm{p}$.

Laiho, R., Prescott, C.E., 2004: Decay and nutrient dynamics of coarse woody debris in northern coniferous forests: a synthesis. Canadian Journal of Forest Research, 34:763-777.

Laing, J., Binyamin, J., 2013: Climate change effect on winter temperature and precipitation of Yellowknife, Northwest Territories, Canada from 1943 to 2011. American Journal of Climate Change, 2:275-283.

Lakida, P. I., Domashovets, G. S., 2009: Biological productivity of L'vov region forests and its dynamics. Korsun'-Shevchenkovckii, FOP Maidachenko, I. S., $254 \mathrm{p}$.

Liang, J., Crowther, T. W., Picard, N., Wiser, S., Zhou, M., Alberti, G. et al., 2016: Positive biodiversity-productivity relationship predominant in global forests. Science, 354:196-208.
Liepa, I. Y, 1980: Dynamics of Wood Stock: Forecast and Ecology. Riga, Zinatne, $170 \mathrm{p}$.

Lieth, H., 1974: Modeling the primary productivity of the world. International Section for Ecology Bulletin, 4:11-20.

Lindner, M., Garcia-Gonzalo, J., Kolstrom, M., Green, T., Reguera, R., Maroschek, M. et al., 2008: Impcats of Climate Change on European Forests and Options for Adaptation. Joensuu, European Forestry Institute, $173 \mathrm{p}$.

Lockers R., Knapen R., Janssen S., van Randen Y., Jansen J., 2016: Analysis of big data technologies for use in agro-environmental science. Environmental Modelling and Software, 84:494-504.

Miao, Z., Li, C., 2011: Predicting tree growth dynamics of boreal forest in response to climate change. In: $\mathrm{Li}$, C. et al. (eds.): Landscape Ecology in Forest Management and Conservation. Berlin, Heidelberg, Higher Education Press, Beijing and Springer-Verlag, p. 176-205.

Mitrofanov, D. P., Kasapenko, L. F., Lapitskaya, L. S., Pashennykh, O. K., 1986: Primary production of forest phytocoenoses at the Middle Yenisei river. In: Forest vegetation resouces of the Middle Siberia. Krasnoyarsk, V.N. Sukachev Forest Institute, p. 3-9.

Ni, J., Zhang, X.-S., Scurlock, J. M. O., 2001: Synthesis and analysis of biomass and net primary productivity in Chinese forests. Annals of Forest Science, 58:351-384.

Odinak, Ya. P., Borsuk, D. V., Granatyr', V. F. et al., 1986: Primary productivity of Fagus-Abies phytocoenoses on Beskidy Mountain. Forestry, Pulp and Wood Industry. Kiev, Budivelnik, 17:13-15.

Onuchin, A. A., Borisov, A. N., 1983: Influence of darkconiferous forests of Khamar-Daban Mountains on snow cover forming. In: Environmental role of Siberian forest ecosystems. Krasnoyarsk, V. N. Sukachev Institute, p. 95-105.

Oohata, S., Oniishi, C., 1974: Some discussions on tree form and dry matter production of a fir stand at Tanohara on Mount Ontake. Bulletin of Kyoto University Forest, 46:51-57.

Opritova, S. V., Glagolev, V. A., Rozenberg, V. A., 1982: On a possibility of estimating aboveground forest biomass using forest inventory data. In: Biogeocenological studies in forests of southern Sikhote-Alin' Mountains. Vladivostok, Far-Eastern Scientific Center, p. 71-83.

Orlov, A. Ya., 1951: Dark-coniferous forests of the Northern Caucasus. Moscow, Academy of Sciences USSR, $256 \mathrm{p}$.

Oshima, Y., Kimura, M., Iwaki, H., Kuroiwa, S., 1958: Ecological and physiological studies on the vegetation of Mt. Shimagare. I. Preliminary survey of the vegetation of Mt. Shimagare. The Botanical magazine, Tokyo, 71:289-301. 
Paquette, A., Vayreda, J., Coll, L., Messier, C., Retana J., 2018: Climate change could negate positive tree diversity effects on forest productivity: A study across five climate types in Spain and Canada. Ecosystems, 21:960-970.

Parresol, B. R., 2001: Additivity of nonlinear biomass equations. Canadian Journal of Forest Research, 31:865-878.

Picard, N., Saint-André, L., Henry, M., 2012: Manual for building tree volumeand biomass allometric equations: from field measurement to prediction. Food and Agricultural Organization of the United Nations, Rome, and Centre de Coopération Internationale en Recherche Agronomique pour le Développement, Montpellier, $215 \mathrm{p}$.

Poorter, L. L., van der Sande, M. T., Thompson, J., Arets, E. J. M. M., Alarcón, A., Álvarez-Sánchez, J. et al., 2015: Diversity enhances carbon storage in tropical forests. Global Ecology and Biogeography, 24:1314.

Poudel, B. C., Sathre, R., Gustavsson, L., Bergh, J., Lundström, A., Hyvönen, R., 2011: Effects of climate change on biomass production and substitution in north-central Sweden. Biomass and Bioenergy, 35:4340-4355.

Sanquetta, C. R., Behling, A., Corte1, A. P. D., Netto, S. P., Schikowski, A. B., do Amaral, M. K., 2015: Simultaneous estimation as alternative to independent modeling of tree biomass. Annals of Forest Science, 72:1099-1112.

Satoo, T., 1973: Materials for the studies of growth in forest stands. XI: Primary production relations in a young plantation of Abies sachalinensis in Hokkaido. Bulletin of Tokyo University Forests, 66:127-137.

Savill, P., Wilson, S., McG., Mason, B., Jinks, R., 2016: Silver Firs (Abies spp) of Europe and the Near East. Species, silviculture and utilisation potential. Quarterly Journal of Forestry, p. 18-30.

Schwarz, F., 1899: Physiologische Untersuchungen über Dickenwachstum und Holzqualität von Pinus silvestris. Berlin, P. Parey, 404 p.

Shuman, J. K., Shugart, H. H., 2009: Evaluating the sensitivity of Eurasian forest biomass to climate change using a dynamic vegetation model. Environmental Research Letters, 4:1-7.

Stegen, J. C., Swenson, N. G., Enquist, B. J., White, E. P., Phillips, O. L., Jorgensen, P. M. et al., 2011: Variation in above-ground forest biomass across broad climatic gradients. Global Ecology and Biogeography, 20:744-754.

Strömgren, M., Linder, S., 2002: Effects of nutrition and soil warming on stem wood production of a boreal Norway spruce stand. Global Change Biology, 8:1195-1204.

Šebeň, V., Konôpka, B., Pajtík, J., 2017:Quantifying carbon in dead and in living trees: a case study in young beech and spruce over 9 years. Central European Forestry Journal, 2-3:133-141.
Tadaki, Y., Sato, A., Sakurai, S., Takeuchi, I., Kawahara, T., 1977: Studies on the production structure of forest. XVII. Structure and primary production in subalpine "dead tree strips" Abies forest near Mount Asahi. Japan. Journal of Ecology, 27:83-90.

Tolmachev, A. I., 1962: Osnovy ucheniya ob arealakh: Vvedenie v khorologiyu rasteniy (Fundamentals of Plant Habitat Theory: Introduction to Plant Community Chorology), Leningrad, State University Publishing, $100 \mathrm{p}$.

Toromani, E. i Bojaxhi, F., 2010: Growth Response of Silver Fir and Bosnian Pine from Kosovo. South-East European Forestry, 1:20-27.

Ueda, S., 1974: Investigation on the nutrients circulation in the mixed natural forest of Todo-matsu (Abies sachalinensis Mast.) and broadleaved trees. Bulletin of Kyoto University Forests, 46:23-39.

Usoltsev, V. A., 2004: On the application of regression analysis in forestry problems. Lesnaya Taksatsiya $\mathrm{i}$ Lesoustroistvo, 1:49-55.

Usoltsev, V.A., 2007: Some methodological and conceptual uncertainties in estimating the income component of the forest carbon cycle. Russian Journal of Ecology, 38:11-10.

Usoltsev, V. A., 2010: Eurasian forest biomass and primary production data. Yekaterinburg, Ural Branch of Russian Academy of Sciences, 570 p.

Usoltsev, V. A., 2013: Forest biomass and primary production database for Eurasia: CD-version. The second ed., enlarged and re-harmonized. Yekaterinburg, Ural State Forest Engineering University.

Usoltsev, V. A., 2018: In basements of the biosphere: What we know about the primary production of tree roots? Eko-Potencial, 24:24-77.

Usoltsev, V. A., Antropov, A. I., 2001: Biomass yield tables for fir forests of Altai-Sayany Mountain Province. Ural Forests and their Management, 21:159170.

Usoltsev, V.A., Vorobeichik, E. L., Bergman, I. E., 2012: Biological productivity of Ural forests under conditions of air pollutions: studying a system of regularities. Yekaterinburg, Ural State Forest Engineering University, $366 \mathrm{p}$.

Usoltsev, V. A., Shobairi, S. O. R., Chasovskikh, V. P., 2019a: Modeling the additive stand biomass of Larix spp. for Eurasia. Ecological Questions, 30:35-46.

Usoltsev, V. A., Shobairi, S. O. R., Tsepordey, I. S., Chasovskikh, V. P., 2019b: Modelling forest stand biomass and net primary production with the focus on additive models sensitive to climate variables for two-needled pines in Eurasia. Journal of Climate Change, 5:41-49.

Veselov, I. V., 1973: Mixed fir and beech forests at the Northern Caucasus and their biological productivity. Krasnodar, Book Publ. House, 211 p.

Vyskot, M., 1972: Aerial biomass of silver fir (Abies alba Mill.). Acta Universitatis Agriculturae (Brno), Series C, 41:243-294. 
Vyskot, M., 1973: Root biomass of silver fir (Abies alba Mill.).Acta Universitatis Agriculturae (Brno), Series C, 42:215-261.

Wilmking, M., Juday, G. P., Barber, V. A., Zald, H. S. J., 2004: Recent climate warming forces contrasting growth responses of white spruce at treeline in Alaska through temperature thresholds. Global Change Biology, 10:1724-1736.

World Weather Maps, 2007. (URL: https://www.mapsofworld.com/referrals/weather/).

Yamamoto, T., Sanada, E., 1970: Nutrients uptake by planted Todo-fir (Abies sachalinensis Mast.), nutrient circulation and a change of soil in forest land. Bull. Government. Forest Experimetal. Station of Tokyo, 229:93-121.

Yoda, K., 1967: A preliminary survey of the forest vegetation of eastern Nepal. II. General description, structure and floristic composition of the sample plots chosen from different vegetation zones. Journal of the College of Arts and Sciences. Chiba University, 5:99-140.

Yoda, K., 1968: A preliminary survey of the forest vegetation of eastern Nepal. III. Plant biomass in the sample plots chosen from different vegetation zones. Journal of the College of Arts and Sciences, Chiba University, 5:277-302.
Young, H. E., Strand, L., Altenberger, R., 1964: Preliminary fresh and dry weight tables for seven tree species in Maine. Maine Agricultural Experiment Station, Technical Bulletin 12, $76 \mathrm{p}$.

Zeller L., Liang J., Pretzsch H., 2018: Tree species richness enhances stand productivity while stand structure can have opposite effects, based on forest inventory data from Germany and the United States of America. Ecosystems, 5:4.

Zheng, C., Mason, E. G., Jia, L., Wei, S., Sun, C., Duan, J., 2015: A single-tree additive biomass model of Quercus variabilis Blume forests in North China. Trees, 29, 3:705-716.

Zeng, W.S., Duo, H. R., Lei, X. D., Chen, X. Y., Wang, X. J., Pu, Y., Zou, W. T., 2017: Individual tree biomass equations and growth models sensitive to climate variables for Larix spp. in China. European Journal of Forest Research, 136:233-249. 